In cooperation with the U.S. Air Force, Air Logistics Center, Kelly Air Force Base, Environmental Management Office

\title{
Gain-Loss Study of Lower San Pedro Creek and the San Antonio River, San Antonio, Texas, May-October 1999
}

Open-File Report 02-023

U.S. Department of the Interior U.S. Geological Survey 
U.S. Department of the Interior

U.S. Geological Survey

\section{Gain-Loss Study of Lower San Pedro Creek and the San Antonio River, San Antonio, Texas, May-October 1999}

By D.J. Ockerman

U.S. GEOLOGICAL SURVEY

Open-File Report 02-023

In cooperation with the U.S. Air Force, Air Logistics Center, Kelly Air Force Base, Environmental Management Office 


\section{U.S. DEPARTMENT OF THE INTERIOR}

Gale A. Norton, Secretary

\section{U.S. GEOLOGICAL SURVEY}

Charles G. Groat, Director

Any use of trade, product, or firm names is for descriptive purposes only and does not imply endorsement by the U.S. Government.

For additional information write to

\section{District Chief}

U.S. Geological Survey

8027 Exchange Dr.

Austin, TX 78754-4733

E-mail: dc_tx@usgs.gov

Copies of this report can be purchased from

U.S. Geological Survey

Branch of Information Services

Box 25286

Denver, CO 80225-0286

E-mail: infoservices@usgs.gov 


\section{CONTENTS}

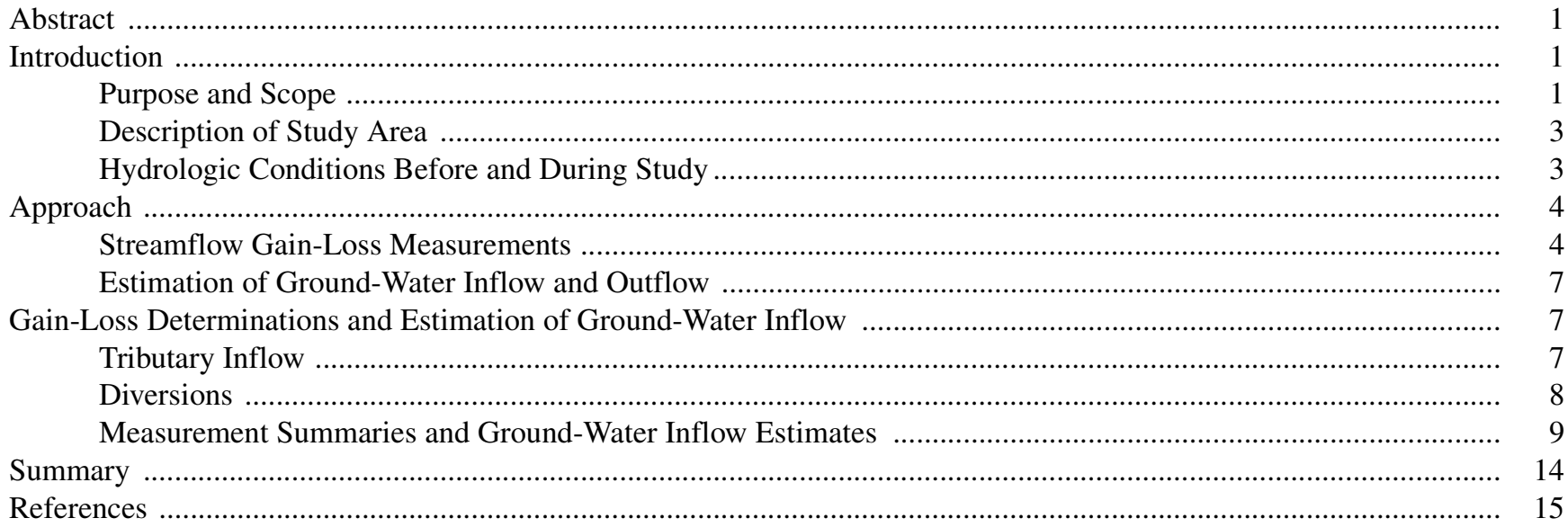

\section{FIGURES}

1. Map showing location of study area and selected data-collection sites ...................................................... 2

2. Photograph showing USGS streamflow-gaging station San Antonio River at Theo Avenue (08178505) .......... 3

3. Graph showing cumulative rainfall, daily mean streamflow, and days of streamflow-measurement surveys, San Pedro Creek and San Antonio River, May-October 1999

4. Photograph showing streamflow measurement at San Antonio River dam spillway near Padre Park, July 1999

5. Schematic diagram of subreaches showing streamflow-measurement sites, streamflow-gaging stations, inflows, diversions, and return flows

6-10. Photographs showing:

6. Confluence of San Pedro Creek and the San Antonio River, July 1999 ............................................ 8

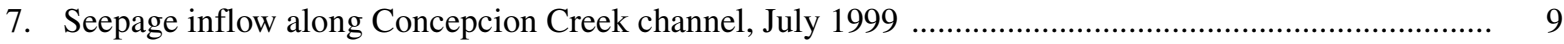

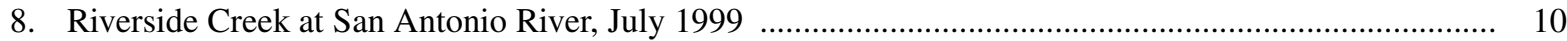

9. Seepage along west bank of San Antonio River, above Mission Road, July 1999 ............................... 10

10. San Antonio River diversion to Padre Park Acequia, July 1999 ........................................................... 11

\section{TABLES}

1. Monthly rainfall and departure from normal, January-October 1999

2. Location of streamflow-measurement sites and streamflow-gaging stations, San Pedro Creek and San Antonio River

3. Subreaches for gain-loss estimates, San Pedro Creek and San Antonio River

4. Summary of gain-loss determinations for subreaches along San Pedro Creek and the San Antonio River during streamflow-measurement surveys, May-October 1999

5. Summary of tributary discharges (attributed to shallow ground-water inflow) to subreaches along San Pedro Creek and the San Antonio River during streamflow-measurement surveys, May-October 1999

6. Summary of estimated shallow ground-water inflow for subreaches along San Pedro Creek and the San Antonio River during streamflow-measurement surveys, May-October 1999

1
1
1
3
3
4
4
7
7
7
8
9
4
15




\title{
Gain-Loss Study of Lower San Pedro Creek and the San Antonio River, San Antonio, Texas, May-October, 1999
}

\author{
By D.J. Ockerman
}

\section{Abstract}

Five streamflow gain-loss measurement surveys were made along lower San Pedro Creek and the San Antonio River from Mitchell Street to South Loop 410 east of Kelly Air Force Base in San Antonio, Texas, during May-October 1999. All of the measurements were made during dry periods, when stormwater runoff was not occurring and effects of possible bank storage were minimized. San Pedro Creek and the San Antonio River were divided into six subreaches, and streamflow measurements were made simultaneously at the boundaries of these subreaches so that streamflow gains or losses and estimates of inflow from or outflow to shallow ground water could be quantified for each subreach. There are two possible sources of ground-water inflow to lower San Pedro Creek and the San Antonio River east of Kelly Air Force Base. One source is direct inflow of shallow ground water into the streams. The other source is ground water that enters tributaries that flow into the San Antonio River. The estimated mean direct inflow of ground water to the combined San Pedro Creek and San Antonio River study reach was 3.0 cubic feet per second or 1.9 million gallons per day. The mean tributary inflow of ground water was estimated to be 1.9 cubic feet per second or 1.2 million gallons per day. The total estimated inflow of shallow ground water was 4.9 cubic feet per second or 3.2 million gallons per day. The amount of inflow from springs and seeps (estimated by observation) is much less than the amount of direct ground-water inflow estimated from the gain-loss measurements. Therefore, the presence of springs and seeps might not be a reliable indicator of the source of shallow ground water entering the river. Most of the shal- low ground water that enters the San Antonio River from tributary inflow enters from the west side, through Concepcion Creek, inflows near Riverside Golf Course, and Six-Mile Creek.

\section{INTRODUCTION}

Organic compounds, including tetrachloroethene (PCE) and trichloroethene (TCE), have been detected in the shallow aquifer near Kelly Air Force Base (AFB) in southwestern San Antonio, Texas. These compounds might be moving with shallow ground water eastward toward the San Antonio River (fig. 1). The interaction between the shallow aquifer and the San Antonio River east of Kelly AFB, and the conditions (ground-water levels and river discharge) under which the river gains or loses streamflow to the aquifer are not well understood. In May 1999, the U.S. Geological Survey (USGS), in cooperation with the U.S. Air Force, began an investigation of lower San Pedro Creek, a tributary to the San Antonio River northeast of Kelly AFB, and the San Antonio River east of Kelly AFB to determine if shallow ground water is entering the river and if so, the locations and quantities.

\section{Purpose and Scope}

The purpose of this report is to present the results of a study to determine if the San Pedro Creek and San Antonio River reaches identified above are gaining or losing streamflow, where the gains or losses are occurring, and if streamflow gains or losses can be attributed to shallow ground-water interaction with the river.

Results of streamflow gain-loss measurements along San Pedro Creek from Furnish Avenue to the San Antonio River and along the San Antonio River between the USGS streamflow-gaging station at Mitchell Street and the USGS streamflow-gaging station at South Loop 410 during May-October 1999 are presented. 


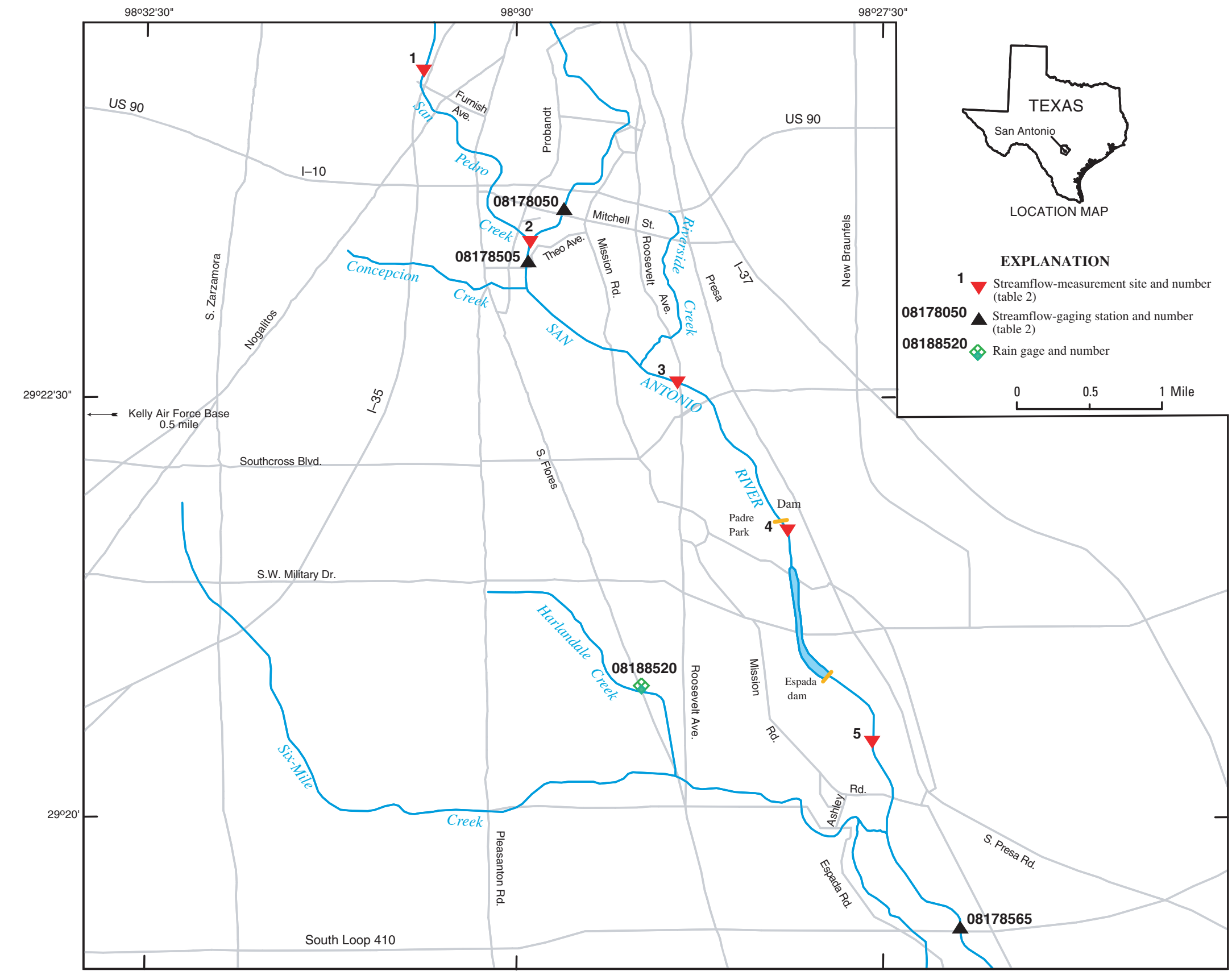

Figure 1. Location of study area and selected data-collection sites. 


\section{Description of Study Area}

The study area comprises the reach of San Pedro Creek from Furnish Avenue to the confluence with the San Antonio River and the San Antonio River from Mitchell Street to South Loop 410 (fig. 1). The USGS operates streamflow-gaging stations on the San Antonio River at Mitchell Street (08178050) (about 1,600 ft above San Pedro Creek), at Theo Avenue (08178505) (about $600 \mathrm{ft}$ below San Pedro Creek) (fig. 2), and at

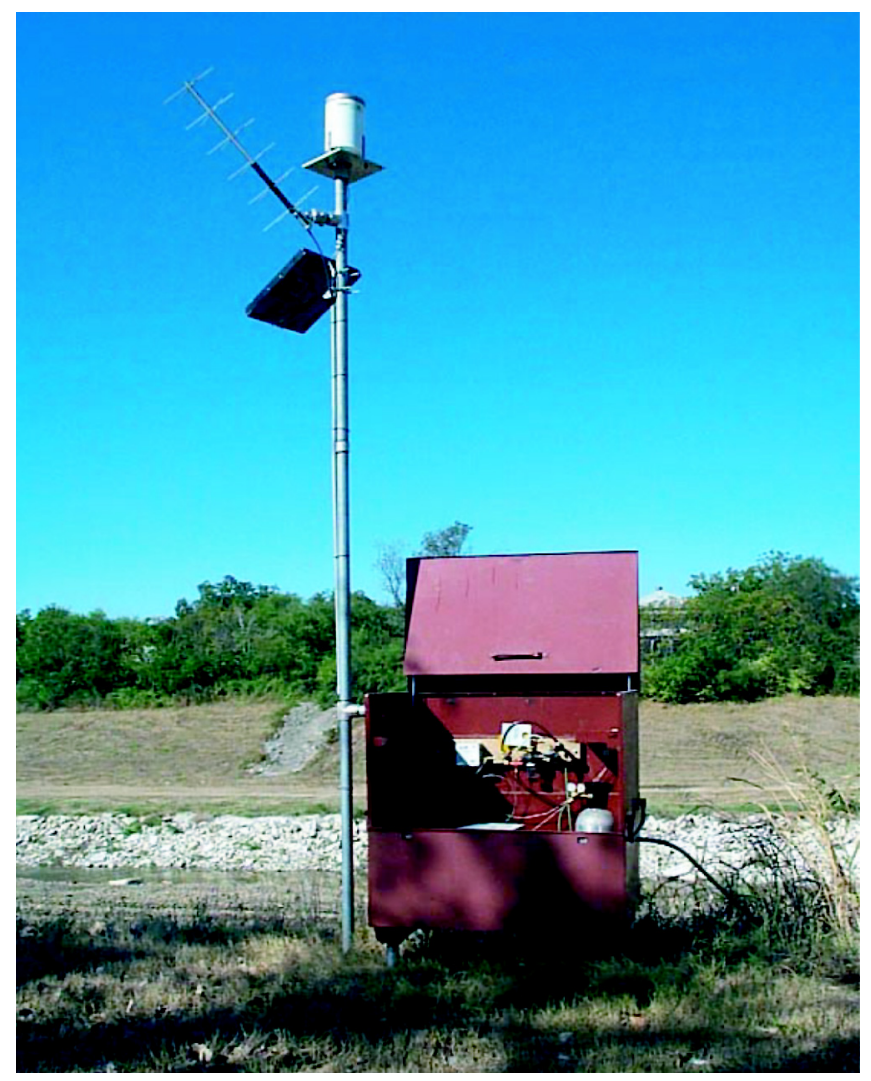

Figure 2. USGS streamflow-gaging station San Antonio River at Theo Avenue (08178505).
South Loop 410 (08178565). The stream length between Furnish Avenue and South Loop 410 is 7.81 mi. The change in stream elevation between the two sites is about $110 \mathrm{ft}$.

Base flow in the San Antonio River originates from San Antonio Springs (an Edwards aquifer spring), which is above downtown San Antonio (not shown in fig. 1). During the 1998 water year (October 1, 1997, to September 30,1998), the median daily mean flow was $15 \mathrm{ft}^{3} / \mathrm{s}$ at the Mitchell Street station. Only 10 percent of the daily mean flows exceeded $72 \mathrm{ft}^{3} / \mathrm{s}$ at the Mitchell Street station (10 percent exceeded $127 \mathrm{ft}^{3} / \mathrm{s}$ at the South Loop 410 station). Ninety percent of the daily mean flows exceeded $7.8 \mathrm{ft}^{3} / \mathrm{s}$ at Mitchell Street $(9.0$ $\mathrm{ft}^{3} / \mathrm{s}$ at South Loop 410). During storm events, runoff can cause much greater discharges. The peak discharges in 1998 were $3,150 \mathrm{ft}^{3} / \mathrm{s}$ at Mitchell Street and 7,120 $\mathrm{ft}^{3} / \mathrm{s}$ at South Loop 410.

Two dams are on the San Antonio River in the study area. The upstream dam is near Padre Park (fig. 1). Espada dam is about 1.1 mi below Padre Park and about 0.3 mi below S.W. Military Drive (fig. 1). No mechanisms control releases from the dams, and flow occurs over the tops of the dams.

\section{Hydrologic Conditions Before and During Study}

Rainfall was below normal before and during the study. Rainfall during January-October 1999 was about 10 in. below normal (table 1). However, the June rainfall of $5.54 \mathrm{in}$. was above normal and might have helped sustain base flow from tributaries and seeps through the dry months of July-October. Figure 3 is a rainfall and discharge hydrograph for the period May-October 1999 showing daily mean streamflow (South Loop 410 station) and days of the streamflow-measurement surveys.

Table 1. Monthly rainfall ${ }^{1}$ and departure from normal ${ }^{2}$, January-October 1999

[In inches]

\begin{tabular}{lccccccccccc}
\hline & Jan. & Feb. & Mar. & Apr. & May & June & July & Aug. & Sept. & Oct. & Total \\
\hline Rainfall & 0.06 & 0.02 & 3.51 & 1.43 & 1.50 & 5.54 & 1.76 & 1.17 & 0.18 & 1.60 & 16.77 \\
Departure & -1.65 & -1.77 & 1.99 & -1.07 & -2.72 & 1.73 & -.40 & -1.37 & -3.23 & -1.57 & -10.06 \\
\hline
\end{tabular}

${ }^{1}$ Rainfall during study computed as average from two USGS rain gages: Harlandale Creek outfall at South Flores Street (08188520) (fig. 1) and Zarzamora Creek outfall at Alderette Park (08178430) (not shown in fig. 1).

${ }^{2}$ Departure from normal computed as the difference between long-term average rainfall obtained from National Oceanic and Atmospheric Administration weather station at San Antonio airport (about 10 miles north of Mitchell Street gaging station) and rainfall during study. 


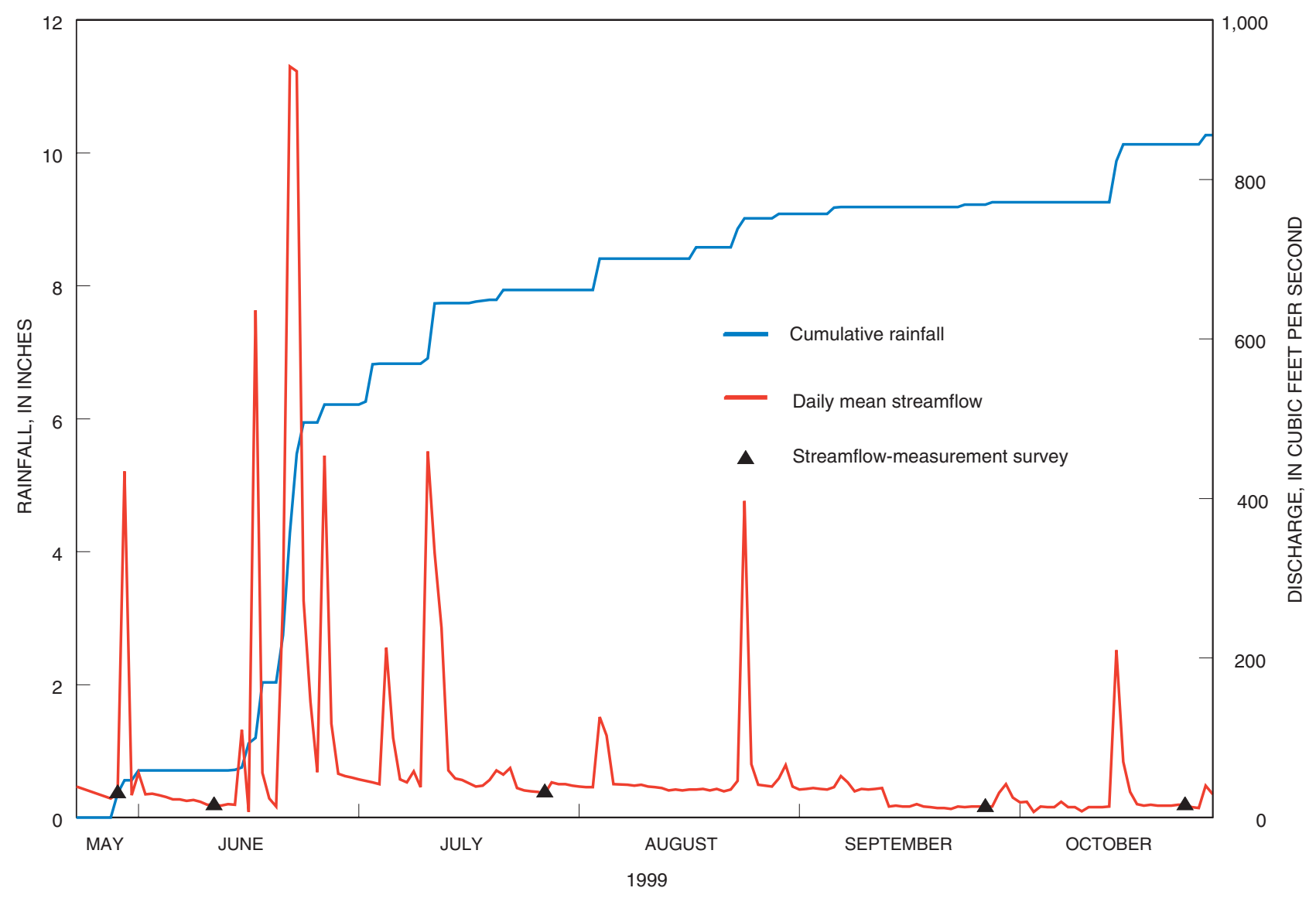

Figure 3. Cumulative rainfall, daily mean streamflow, and days of streamflow-measurement surveys, San Pedro Creek and San Antonio River, May-October 1999.

As seen in figure 3, rainfall events and resulting increases in streamflow were more frequent during late May-mid-July than during August-October. Figure 3 also shows when the measurement surveys were made. The streamflow-measurement surveys were made during base-flow conditions. During the five measurement surveys, the San Antonio River discharge (average of measurements at Theo Avenue and South Loop 410) ranged from 15.2 to $30.8 \mathrm{ft}^{3} / \mathrm{s}$. The average discharge was $21.0 \mathrm{ft}^{3} / \mathrm{s}$.

\section{APPROACH}

\section{Streamflow Gain-Loss Measurements}

To determine whether the river is gaining or losing streamflow and where gains or losses might be occurring, streamflow-measurement surveys were made on May 26, June 8, July 27, September 27, and October 27,1999 . During each survey, simultaneous (within about 3 hours) streamflow measurements were made at selected sites along the study reach. The measurements were made by the current-meter velocity-area method (Rantz and others, 1982). Two measurements often were made at each site during each measurement survey. When two measurements were made, the mean streamflow was used for gain-loss computations. The estimated typical error of streamflow measurements during this study, considering measurement and flow conditions, was 5 percent of the measured streamflow. Figure 4 shows a USGS technician making a streamflow measurement at the dam spillway near Padre Park.

During each survey, measurements were made at the Mitchell Street, Theo Avenue, and South Loop 410 stations (table 2). Streamflow measurements also were made at five intermediate sites, two on San Pedro Creek and three on the San Antonio River. In addition, tributary flows and diversions were measured or estimated during each survey. The location of measurement sites and gaging stations determined subreaches for which 


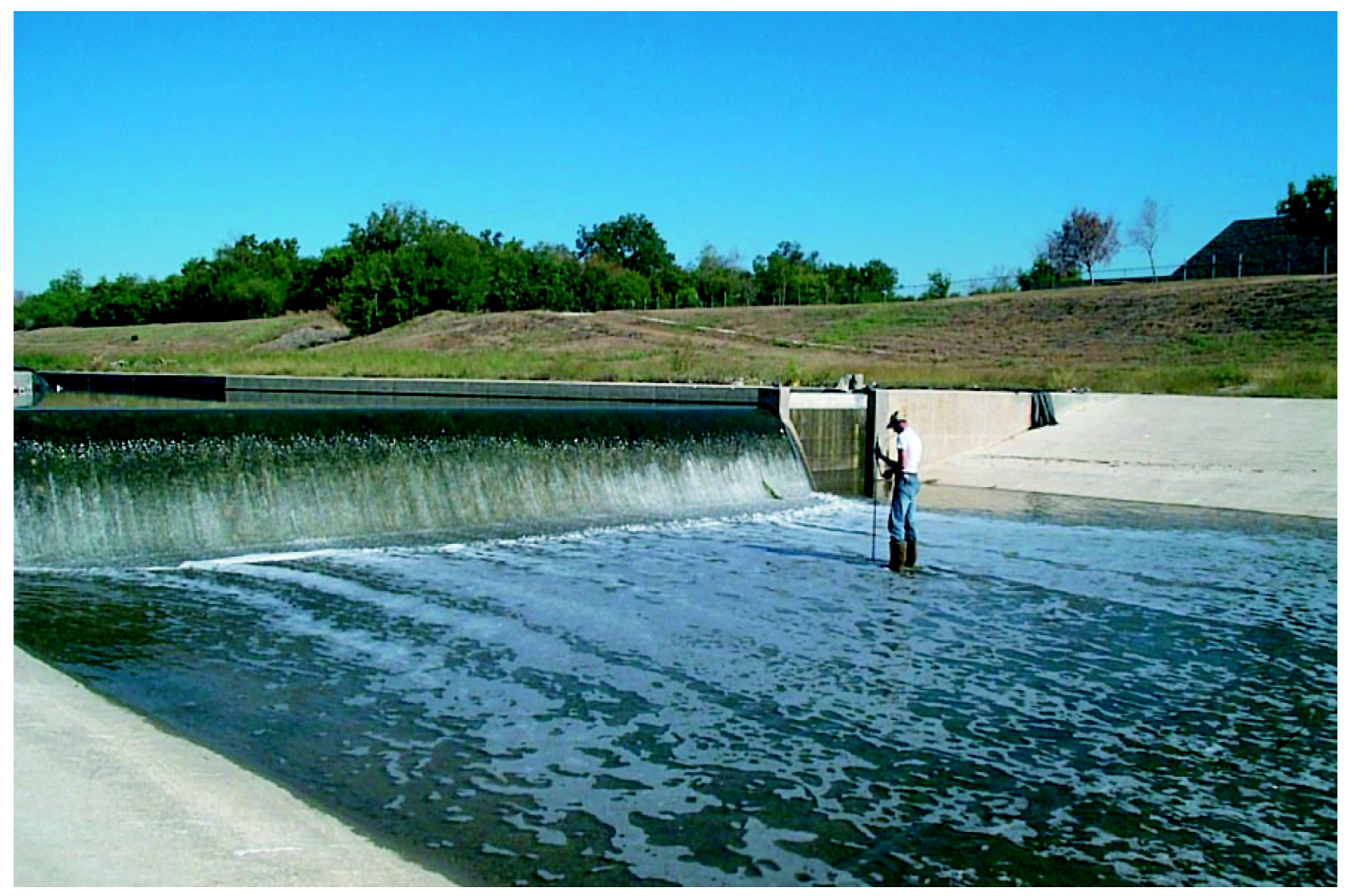

Figure 4. Streamflow measurement at San Antonio River dam spillway near Padre Park, July 1999.

Table 2. Location of streamflow-measurement sites and streamflow-gaging stations, San Pedro Creek and San Antonio River

\begin{tabular}{|c|c|c|}
\hline $\begin{array}{c}\text { Streamflow- } \\
\text { measurement site } \\
\text { or gaging station no. } \\
\text { (fig. 1) }\end{array}$ & Description & Location \\
\hline 1 & San Pedro Creek at Furnish Avenue & 1.60 miles above confluence with San Antonio River \\
\hline 2 & San Pedro Creek at San Antonio River & At confluence with San Antonio River \\
\hline 08178050 & $\begin{array}{l}\text { USGS gaging station San Antonio } \\
\text { River at Mitchell Street }\end{array}$ & 1,600 feet above San Pedro Creek \\
\hline 08178505 & $\begin{array}{l}\text { USGS gaging station San Antonio } \\
\text { River at Theo Avenue }\end{array}$ & 600 feet below San Pedro Creek \\
\hline 3 & $\begin{array}{l}\text { San Antonio River at Roosevelt } \\
\text { Avenue }\end{array}$ & 1.54 miles below Theo Avenue gaging station \\
\hline 4 & San Antonio River at Padre Park dam & $\begin{array}{l}1.26 \text { miles below Roosevelt Avenue, } 1.12 \text { miles above } \\
\text { Espada dam }\end{array}$ \\
\hline 5 & San Antonio River at Ashley Road & $\begin{array}{l}0.85 \text { mile below Espada dam, 1,100 feet above Ashley } \\
\text { Road bridge }\end{array}$ \\
\hline 08178565 & $\begin{array}{l}\text { USGS gaging station San Antonio } \\
\text { River at South Loop } 410\end{array}$ & 1.14 miles below Ashley Road bridge \\
\hline
\end{tabular}




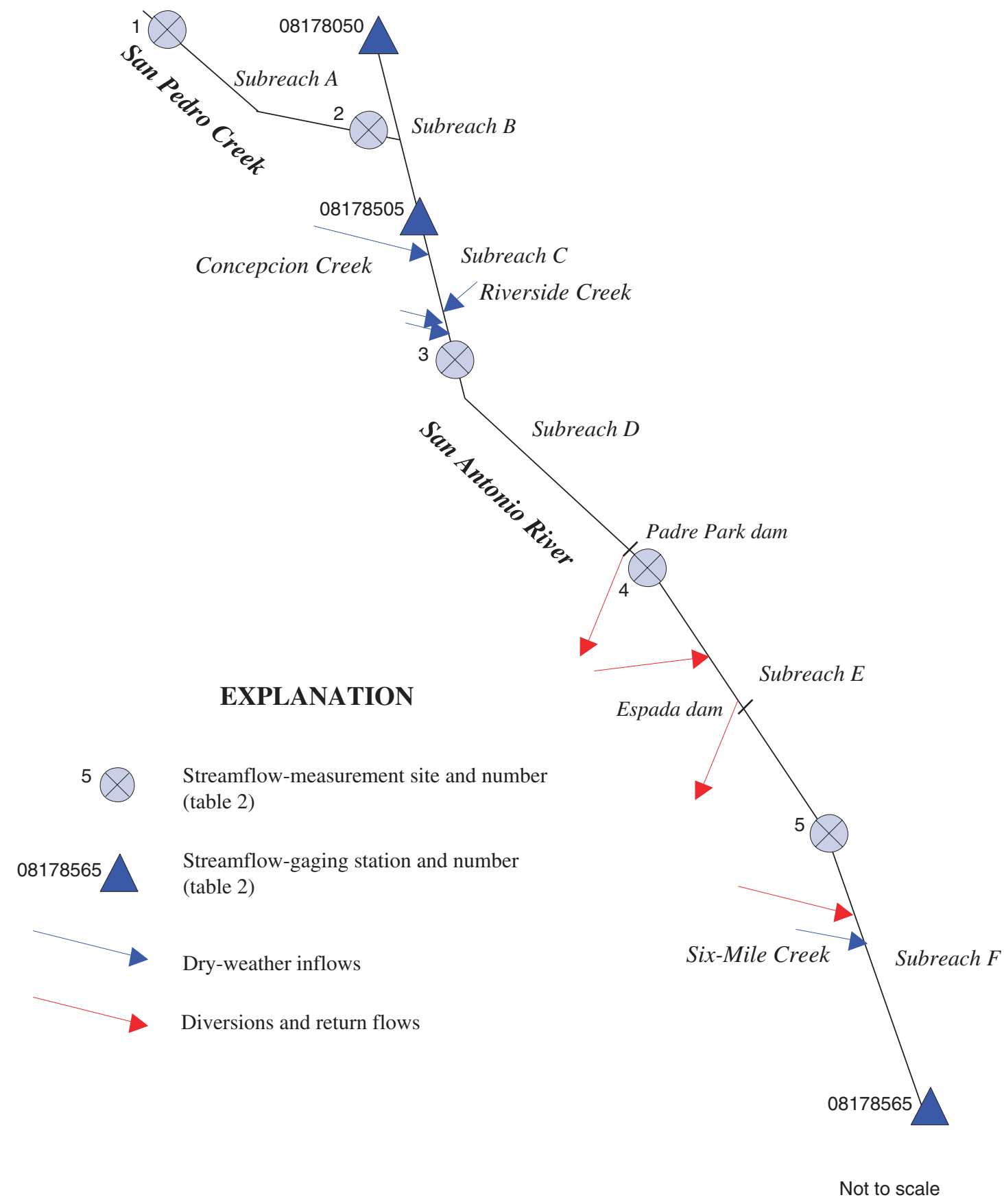

Figure 5. Schematic diagram of subreaches showing streamflow-measurement sites, streamflow-gaging stations, inflows, diversions, and return flows.

gains or losses could be computed as the difference in streamflow measured at the upstream and downstream boundaries of the subreaches (fig. 5; table 3).

During the May 26 survey, measurements were not made at the Furnish Avenue and Roosevelt Avenue intermediate sites. Therefore, subreach A was not included in that survey and subreaches $\mathrm{C}$ and $\mathrm{D}$ were combined as a single subreach, $\mathrm{C}-\mathrm{D}$. Also, during the May 26 and June 8 surveys, measurements were not made at San Pedro Creek at the San Antonio River, so gain-loss estimates for subreaches A and B were not computed for those periods. 
Table 3. Subreaches for gain-loss estimates, San Pedro Creek and San Antonio River

\begin{tabular}{ccll}
\hline $\begin{array}{c}\text { Subreach } \\
\text { (fig. 5) }\end{array}$ & $\begin{array}{c}\text { Length } \\
\text { (miles) }\end{array}$ & $\begin{array}{c}\text { Upstream streamflow-measurement site } \\
\text { or streamflow-gaging station (no.) }\end{array}$ & $\begin{array}{l}\text { Downstream streamflow-measurement } \\
\text { site or streamflow-gaging station (no.) }\end{array}$ \\
\hline $\begin{array}{c}\text { San Pedro Creek } \\
\text { A }\end{array}$ & 1.60 & Furnish Avenue (1) & San Pedro Creek at San Antonio River (2) \\
San Antonio River & & & \\
B & .42 & Mitchell Street station (08178050) & $\begin{array}{l}\text { Theo Avenue station (08178505) } \\
\text { Coosevelt Avenue (3) }\end{array}$ \\
D & 1.54 & Theo Avenue station (08178505) & $\begin{array}{l}\text { Padre Park dam (4) } \\
\text { E }\end{array}$ \\
F & 1.26 & Roosevelt Avenue (3) & $\begin{array}{l}\text { Ashley Road (5) } \\
\text { South Loop 410 station (08178565) }\end{array}$ \\
\hline
\end{tabular}

\section{Estimation of Ground-Water Inflow and Outflow}

Ground-water inflow to the streams or outflow to ground water are not directly measurable because the inflow and outflow processes usually cannot be observed. Even visible inflow from springs and seeps cannot always be measured accurately. Therefore, inflow from or outflow to ground water in subreaches of the streams was measured indirectly by measuring the difference in streamflow at the upstream and downstream ends of the subreaches. Ground-water inflow and outflow are not the only sources of gain or loss along the streams. Other sources are tributary inflow, diversions, return flows, and evaporation. By accounting for these factors, ground-water inflow or outflow can be estimated. Ground-water inflow, $\mathrm{G}$, is estimated as

$$
\mathrm{G}=\mathrm{Q}_{\mathrm{D}}-\mathrm{Q}_{\mathrm{U}}-\mathrm{I}+\mathrm{D}-\mathrm{R}+\mathrm{E}
$$

where

$$
\begin{gathered}
\mathrm{Q}_{\mathrm{D}}=\begin{array}{c}
\text { measured streamflow at the downstream } \\
\text { boundary of the subreach, }
\end{array} \\
\mathrm{Q}_{\mathrm{U}}=\begin{array}{c}
\text { measured streamflow at the upstream boundary } \\
\text { of the subreach, }
\end{array} \\
\mathrm{I}=\begin{array}{c}
\text { measured or estimated inflows from creeks or } \\
\text { tributaries, }
\end{array} \\
\mathrm{D}=\text { diversions in the subreach, } \\
\mathrm{R}=\text { return flows in the subreach, and } \\
\mathrm{E}=\text { estimated evaporation losses. }
\end{gathered}
$$

Evaporation within a subreach was estimated using potential evaporation data from the National Oceanic and Atmospheric Administration (1999) for a station at Sea World in San Antonio (not shown in fig. 1). The daily evaporation rate was applied to the surface area of each subreach to compute an average daily evaporation discharge. Because evaporative losses are assumed to occur primarily during the daytime hours only, the daily pan evaporation was multiplied by the ratio of 24 to hours of daylight to determine the evaporative rate during daytime hours (when measurement surveys were made). Changes in reservoir storage behind the dams in the study reach were considered insignificant because the reservoirs remained full and continuous flow over the dams occurred during the study period.

\section{GAIN-LOSS DETERMINATIONS AND ESTIMATION OF GROUND-WATER INFLOW}

\section{Tributary Inflow}

Several tributaries flow into the San Antonio River between Mitchell Street and South Loop 410. The confluence of San Pedro Creek with the San Antonio River (fig. 6) is about 1,600 ft below the Mitchell Street station. Base flow in San Pedro Creek originates primarily from San Pedro Springs (an Edwards aquifer spring) above the study area, rather than from a shallow ground-water spring.

Concepcion Creek enters the San Antonio River on the west bank about 1,200 ft below the Theo Avenue station. Concepcion Creek had continuous base flow during the study period. Most of the flow appeared to be shallow ground-water seepage entering the Concepcion Creek concrete channel through numerous drainage 


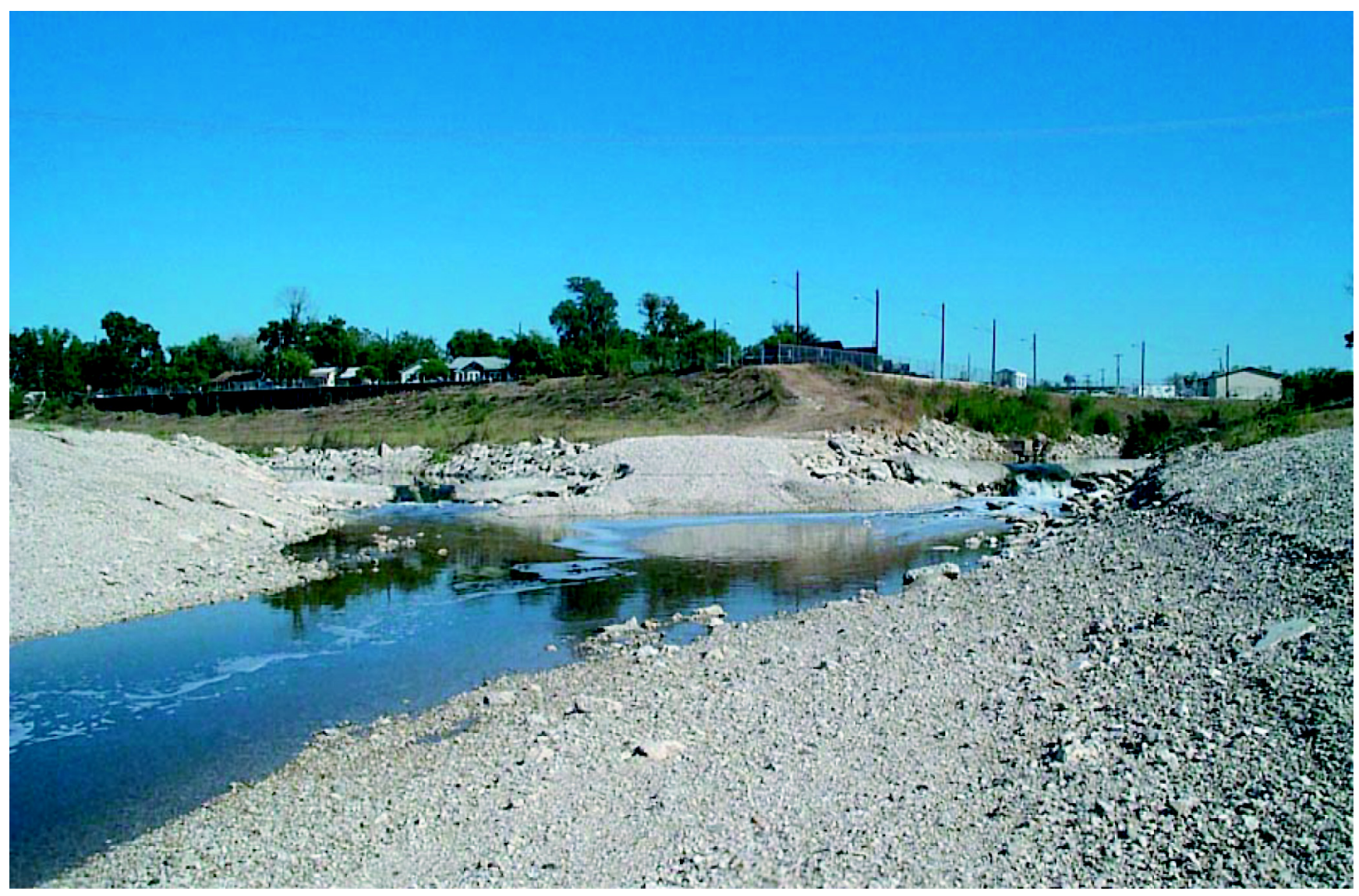

Figure 6. Confluence of San Pedro Creek and the San Antonio River, July 1999.

inlets extending a distance of at least $1 \mathrm{mi}$ above the creek's confluence with the river (fig. 7).

Three other inflows sustained by base flow during the study period are located near the Riverside Golf Course between Mission Road and Roosevelt Avenue. Riverside Creek enters the San Antonio River from the east (fig. 8). The source of flow in the creek is attributed to ground-water inflow. Two culverts discharge to the river along the west bank between Mission Road and Roosevelt Avenue. The source of the discharge probably is shallow ground water. A golf course pond is adjacent to the upstream culvert and might contribute water to the flow. The combined measured streamflow of all three inflows was $1.0 \mathrm{ft}^{3} / \mathrm{s}$ or less during the measurement surveys.

Six-Mile Creek enters the San Antonio River between Ashley Road and South Loop 410. A small base flow (about $0.4 \mathrm{ft}^{3} / \mathrm{s}$ ) was observed during all of the measurement surveys. Numerous springs and seeps have been observed along the banks of both sides of the San Antonio River from Mitchell Street to Roosevelt
Avenue (B. Goodson, CH2M Hill, oral commun., 1999). Because of vegetation or rocks along the riverbanks, the occurrence of seeps is not always apparent. Springs or seeps were not observed from Roosevelt Avenue to South Loop 410. The occurrence of springs and seeps also was more obvious during May and June. However, during the July measurement survey, and especially the September and October surveys, the springs and seeps had diminished. Most of the springs and seeps did not contribute substantial flow to the river. The seepage in figure 9 was estimated at $1.0 \mathrm{gal} / \mathrm{min}$ (about $0.002 \mathrm{ft}^{3} / \mathrm{s}$ ) or less.

\section{Diversions}

Two diversions are important for the gain-loss determinations. One diversion occurs above the dam near Padre Park. This diversion from the San Antonio River (fig. 10) flows through the Padre Park Acequia (historic irrigation ditch) and returns to the river above S.W. Military Drive. No water rights are associated with this diversion (Texas Natural Resource Conservation 


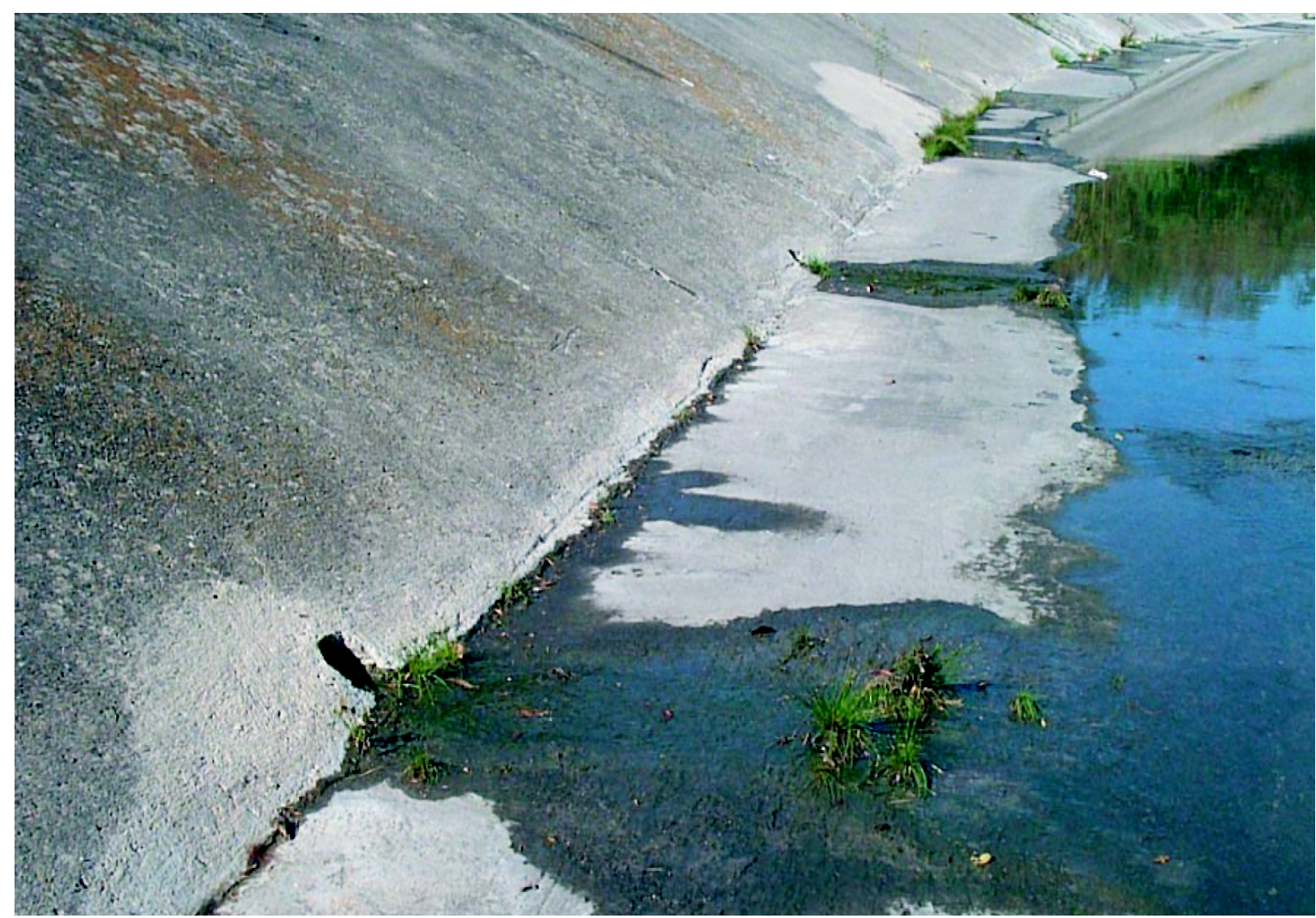

Figure 7. Seepage inflow along Concepcion Creek channel, July 1999.

Commission, 1999). Another diversion occurs at Espada dam. Most of the water returns to the river just below the dam. Some of the water is diverted to Espada ditch (about $3.0 \mathrm{ft}^{3} / \mathrm{s}$ ). Two water rights are associated with the Espada ditch diversion (Texas Natural Resource Conservation Commission, 1999) for a total permitted diversion of 1,366 acre- $\mathrm{ft} / \mathrm{yr}\left(1.9 \mathrm{ft}^{3} / \mathrm{s}\right)$. Some of the Espada ditch diversion (about $1.0 \mathrm{ft}^{3} / \mathrm{s}$ ) is returned to the San Antonio River below Ashley Road. Some of the water returns to the San Antonio River below the South Loop 410 station, beyond the study reach.

\section{Measurement Summaries and Ground-Water Inflow Estimates}

A summary of the gain-loss determinations for each measurement survey is listed in table 4. For each measurement survey, mean streamflow, measured difference between streamflow at upstream and downstream boundaries, tributary inflow, net diversions (diversions minus return flows), estimated evaporation, and estimated ground-water inflow are listed by subreach. The quantities of shallow ground water attributed to tributary inflow are listed in table 5. San Pedro Creek inflow to subreach B is excluded because the source of the San Pedro Creek flow is an Edwards aquifer spring. Estimated ground-water inflow (or streamflow loss to ground water) by subreach for each measurement survey is listed in table 6 . These estimated ground-water inflows (or outflows) do not include ground-water inflow into tributaries that eventually flow into the San Antonio River.

Gain-loss measurements for subreach A were not adequate during May 26 and June 8 to estimate groundwater inflows. On July 27 , a small $\left(0.4 \mathrm{ft}^{3} / \mathrm{s}\right.$ or 0.3 $\mathrm{Mgal} / \mathrm{d}$ ) ground-water inflow to subreach A was indicated by the measurements. For September 27 and October 27, streamflow losses to shallow ground water were 0.3 and $1.1 \mathrm{ft}^{3} / \mathrm{s}(0.2$ and $0.7 \mathrm{Mgal} / \mathrm{d})$. The mean of the three measurement surveys indicates a streamflow loss of $0.3 \mathrm{ft}^{3} / \mathrm{s}$ to shallow ground water. No tributaries contribute to the subreach. 


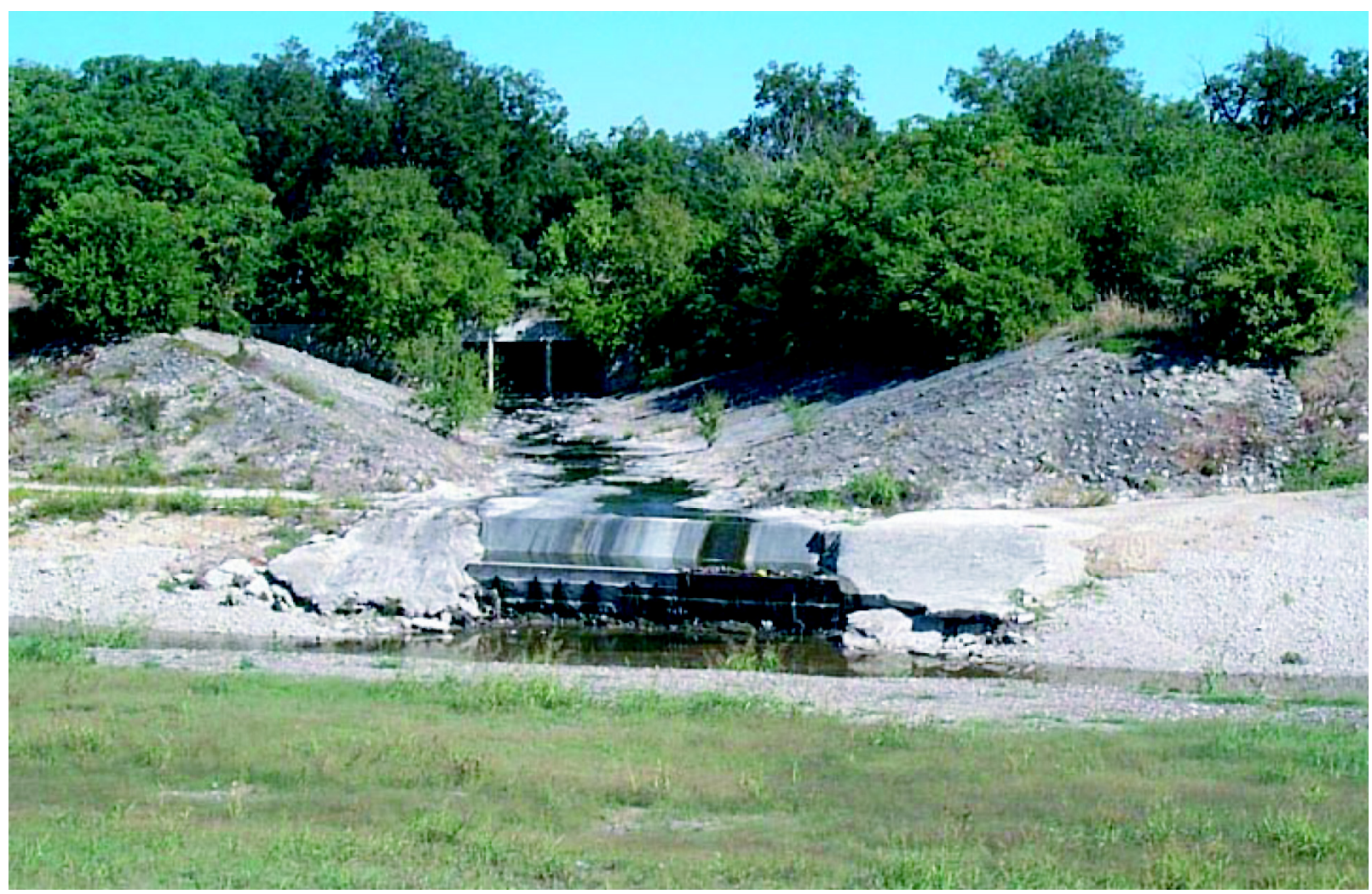

Figure 8. Riverside Creek at San Antonio River, July 1999.

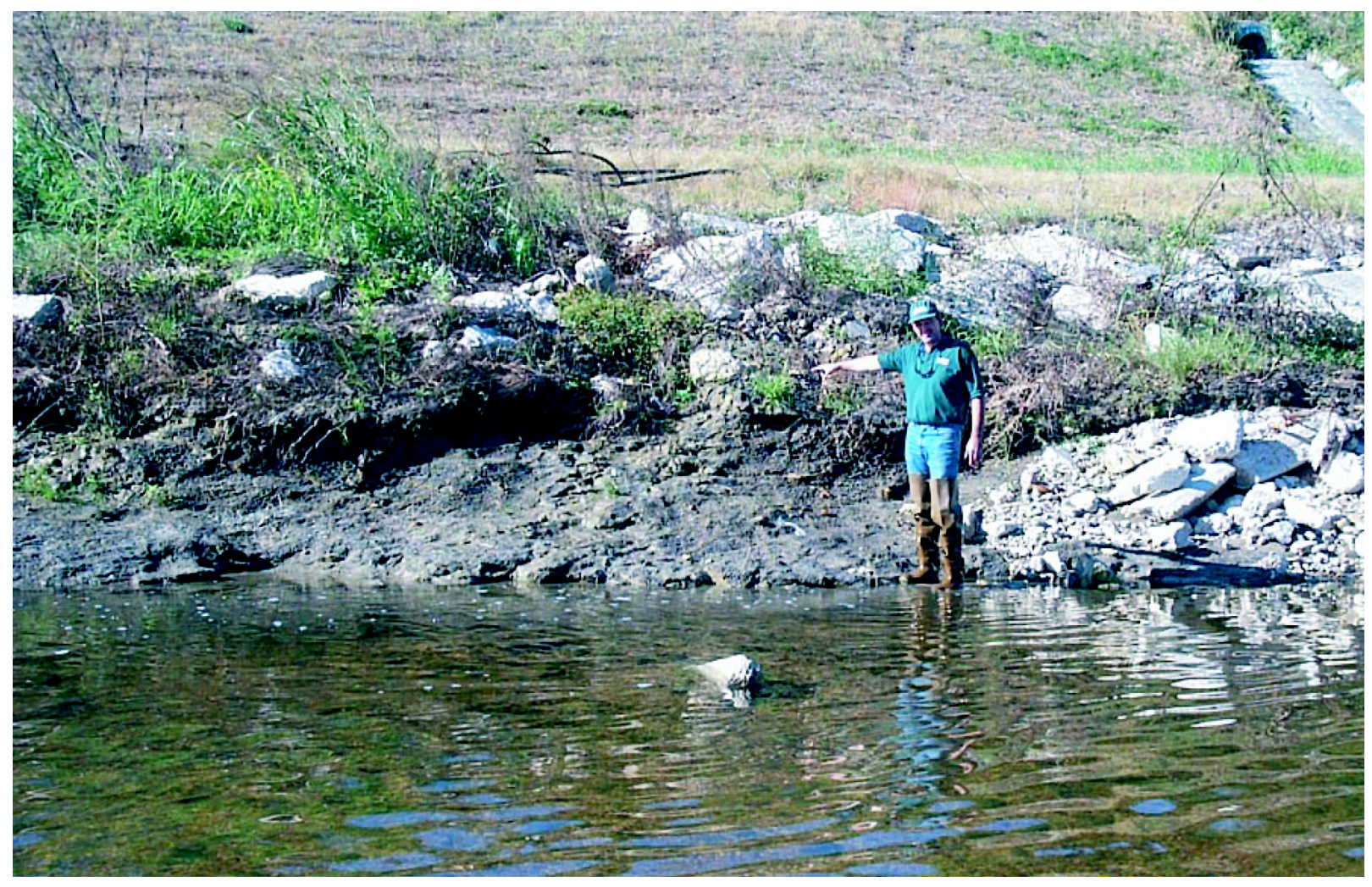

Figure 9. Seepage along west bank of San Antonio River, above Mission Road, July 1999. 


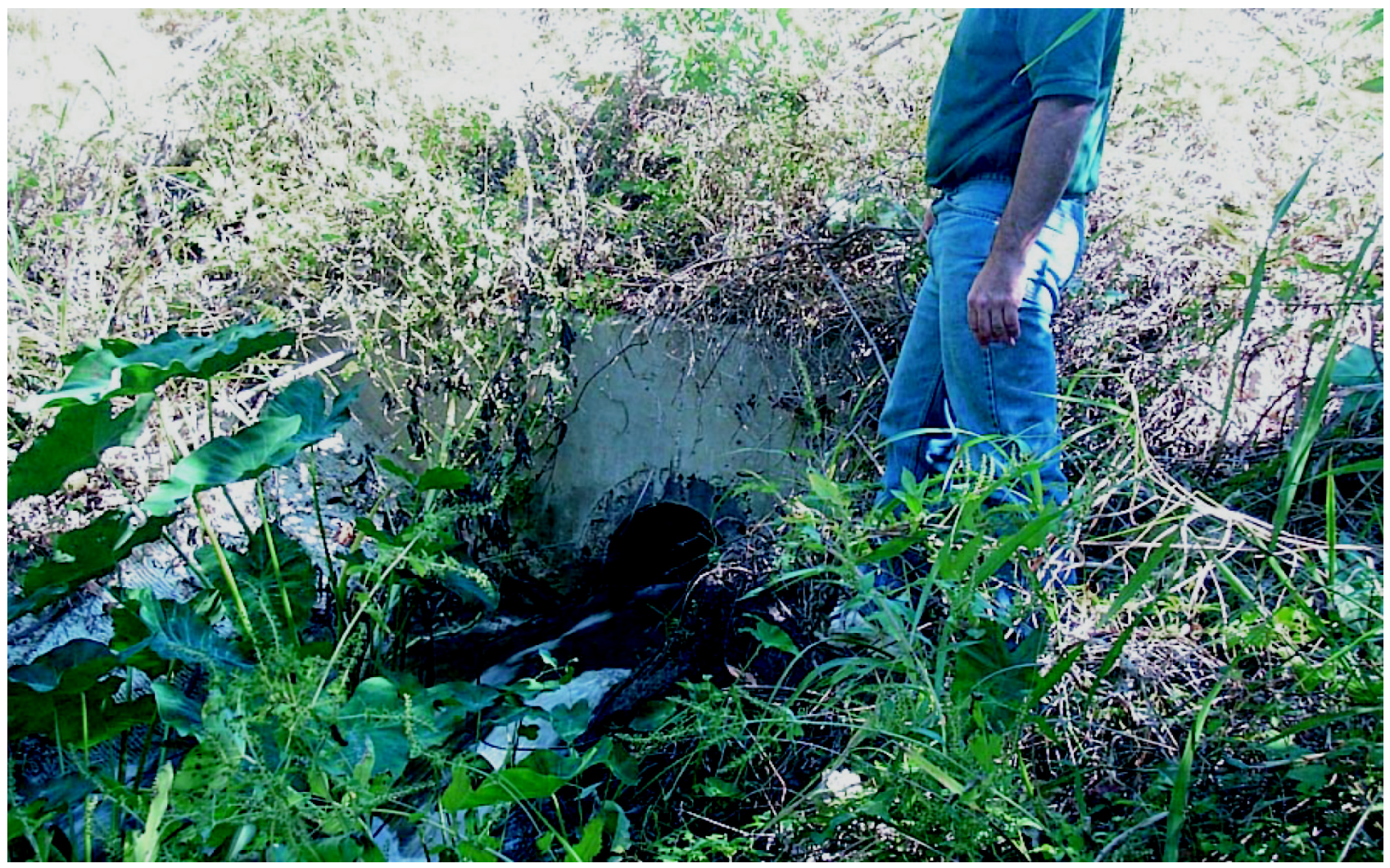

Figure 10. San Antonio River diversion to Padre Park Acequia, July 1999.

Ground-water inflow estimates were made for subreach B for only the July 27, September 27, and October 27 measurement surveys. On July 27, the estimated inflow was $2.1 \mathrm{ft}^{3} / \mathrm{s}(1.4 \mathrm{Mgal} / \mathrm{d})$. On September 27 (after 2 months of below-normal rainfall), groundwater inflow was estimated to be $0.8 \mathrm{ft}^{3} / \mathrm{s}(0.5 \mathrm{Mgal} / \mathrm{d})$. On October 27, the subreach lost $0.3 \mathrm{ft}^{3} / \mathrm{s}(0.2 \mathrm{Mgal} / \mathrm{d})$. For the three measurement surveys, the mean estimated ground-water inflow was $0.9 \mathrm{ft}^{3} / \mathrm{s}(0.6 \mathrm{Mgal} / \mathrm{d})$. No tributaries contribute to the subreach.

Subreach C-D had direct ground-water inflow during all five measurement surveys. On May 26, the estimated direct ground-water inflow was $5.6 \mathrm{ft}^{3} / \mathrm{s}(3.6$ $\mathrm{Mgal} / \mathrm{d})$. During subsequent surveys, subreach C-D was divided into separate subreaches $\mathrm{C}$ and $\mathrm{D}$ by the addition of a measurement site at Roosevelt Avenue. On June 8, September 27, and October 27, subreach C received most of the direct ground-water inflow within subreach C-D. On July 27, most of the inflow occurred in subreach $\mathrm{D}$. The mean estimated ground-water inflow in subreach $\mathrm{C}-\mathrm{D}$ for all of the measurements was $3.1 \mathrm{ft}^{3} / \mathrm{s}(2.0 \mathrm{Mgal} / \mathrm{d})$.
Subreach $\mathrm{C}$ receives tributary inflow from Concepcion Creek, two inflows on the west bank (near Roosevelt Avenue), and Riverside Creek. All of these inflows probably originate from shallow ground water. The average tributary inflow in subreach $\mathrm{C}$ was $1.5 \mathrm{ft}^{3} / \mathrm{s}$ $(1.0 \mathrm{Mgal} / \mathrm{d})$. Subreach $\mathrm{C}$ has no diversions. Subreach D has no tributary inflow but does include the diversion for the Padre Park Acequia, which is returned to the river in subreach $\mathrm{E}$.

Subreach E had an inflow of ground water on May 26. However, during the other measurement surveys, streamflow was lost to ground water. The average streamflow loss (including the May 26 streamflow gain) was $1.1 \mathrm{ft}^{3} / \mathrm{s}(0.7 \mathrm{Mgal} / \mathrm{d})$. No tributaries, diversions, or return flows are in this subreach.

Subreach F showed ground-water inflow during all five measurement surveys. The average estimated inflow was $1.0 \mathrm{ft}^{3} / \mathrm{s}(0.6 \mathrm{Mgal} / \mathrm{d})$. This subreach also receives inflow from Six-Mile Creek. This estimated inflow probably is from shallow ground water. During some of the measurement surveys, an intermittent return flow from Espada ditch entered the river below Ashley Road. 
Table 4. Summary of gain-loss determinations for subreaches along San Pedro Creek and the San Antonio River during streamflow-measurement surveys, May-October 1999

[In cubic feet per second; positive indicates gain, inflow, or return flow entering the subreach; negative indicates loss, outflow, or diversion leaving the subreach. --, not measured or determined]

May 26, 1999

\begin{tabular}{ccccccc}
\hline $\begin{array}{c}\text { Subreach } \\
\text { (see table 3 } \\
\text { for }\end{array}$ & $\begin{array}{c}\text { Mean } \\
\text { streamflow } \\
\text { in subreach }\end{array}$ & $\begin{array}{c}\text { Measured } \\
\text { difference in } \\
\text { streamflow within } \\
\text { subreach }\end{array}$ & $\begin{array}{c}\text { Inflow from creeks } \\
\text { or tributaries } \\
\text { within subreach }\end{array}$ & $\begin{array}{c}\text { Net diversion } \\
\text { in subreach }\end{array}$ & $\begin{array}{c}\text { Estimated } \\
\text { evaporation } \\
\text { loss within } \\
\text { subreach }\end{array}$ & $\begin{array}{c}\text { Estimated } \\
\text { ground-water } \\
\text { inflow within } \\
\text { subreach }\end{array}$ \\
\hline A & -- & -- & 0 & 0 & 0.2 & -- \\
B & 20.4 & 8.0 & 0 & -1 & .1 & -- \\
C-D & 26.4 & 3.9 & 2.0 & -3 & .7 & 5.6 \\
C & -- & 1.0 & 2.0 & 0 & .3 & -- \\
D & -- & 1.0 & 0 & -3 & .4 & - \\
E & 27.7 & -1.2 & 0 & -.3 & 1.2 & .3 \\
F & 27.8 & 1.4 & .4 & 1.2 & .3 & .1 \\
\hline
\end{tabular}

\footnotetext{
${ }^{1}$ Subreaches C and D combined for May 26, 1999, measurement survey.
}

June 8, 1999

\begin{tabular}{ccccccc}
\hline $\begin{array}{c}\text { Subreach } \\
\text { (see table 3 } \\
\text { for }\end{array}$ & $\begin{array}{c}\text { Mean } \\
\text { streamflow } \\
\text { in subreach }\end{array}$ & $\begin{array}{c}\text { Measured } \\
\text { difference in } \\
\text { streamflow within } \\
\text { subreach }\end{array}$ & $\begin{array}{c}\text { Inflow from creeks } \\
\text { or tributaries } \\
\text { within subreach }\end{array}$ & $\begin{array}{c}\text { Net diversion } \\
\text { in subreach }\end{array}$ & $\begin{array}{c}\text { Estimated } \\
\text { evaporation } \\
\text { loss within } \\
\text { subreach }\end{array}$ & $\begin{array}{c}\text { Estimated } \\
\text { ground-water } \\
\text { inflow within } \\
\text { subreach }\end{array}$ \\
\hline A & 5.4 & -- & 0 & 0 & 0.2 & -- \\
B & 12.6 & 6.4 & 0 & .1 & .1 & - \\
C & 17.2 & 2.9 & 2.0 & 0 & .3 & 1.2 \\
D & 17.4 & -2.7 & 0 & -3.0 & .3 & .6 \\
E & 14.6 & -2.9 & 0 & -.3 & 1.1 & -1.5 \\
F & 13.8 & 1.4 & .4 & 1.2 & .3 & .1 \\
\hline
\end{tabular}

July 27, 1999

\begin{tabular}{ccccccc}
\hline $\begin{array}{c}\text { Subreach } \\
\text { (see table 3 } \\
\text { for }\end{array}$ & $\begin{array}{c}\text { Mean } \\
\text { streamflow } \\
\text { in subreach }\end{array}$ & $\begin{array}{c}\text { Measured } \\
\text { difference in } \\
\text { streamflow within } \\
\text { subreach }\end{array}$ & $\begin{array}{c}\text { Inflow from creeks } \\
\text { or tributaries } \\
\text { within subreach }\end{array}$ & $\begin{array}{c}\text { Net diversion } \\
\text { in subreach }\end{array}$ & $\begin{array}{c}\text { Estimated } \\
\text { evaporation } \\
\text { loss within } \\
\text { subreach }\end{array}$ & $\begin{array}{c}\text { Estimated } \\
\text { ground-water } \\
\text { inflow within } \\
\text { subreach }\end{array}$ \\
\hline A & 10.6 & 0.2 & 0 & 0 & 0.2 & 0.4 \\
B & 24.2 & 12.9 & 10.8 & .1 & .1 & 2.1 \\
C & 30.8 & 1.7 & 1.7 & 0 & .3 & .3 \\
D & 32.6 & .5 & 0 & -3.0 & .3 & 3.8 \\
E & 30.8 & -3.9 & 0 & -.3 & 1.0 & -2.6 \\
F & 30.0 & 2.1 & .4 & 1.2 & .2 & .7 \\
\hline
\end{tabular}


Table 4. Summary of gain-loss determinations for subreaches along San Pedro Creek and the San Antonio River during streamflow-measurement surveys, May-October 1999-Continued

September 27, 1999

\begin{tabular}{ccccccc}
\hline $\begin{array}{c}\text { Subreach } \\
\text { (see table 3 } \\
\text { for }\end{array}$ & $\begin{array}{c}\text { Mean } \\
\text { streamflow } \\
\text { in subreach }\end{array}$ & $\begin{array}{c}\text { Measured } \\
\text { difference in } \\
\text { streamflow within } \\
\text { subreach }\end{array}$ & $\begin{array}{c}\text { Inflow from creeks } \\
\text { or tributaries } \\
\text { within subreach }\end{array}$ & $\begin{array}{c}\text { Net diversion } \\
\text { in subreach }\end{array}$ & $\begin{array}{c}\text { Estimated } \\
\text { evaporation } \\
\text { loss within } \\
\text { subreach }\end{array}$ & $\begin{array}{c}\text { Estimated } \\
\text { ground-water } \\
\text { inflow within } \\
\text { subreach }\end{array}$ \\
\hline A & 5.2 & -0.4 & 0 & 0 & 0.1 & -0.3 \\
B & 13.1 & 5.8 & 5.0 & .1 & .1 & .8 \\
C & 16.8 & 1.6 & 1.0 & 0 & .2 & .8 \\
D & 16.2 & -2.9 & 0 & -3.0 & .3 & .4 \\
E & 13.9 & -1.6 & 0 & -.3 & .9 & -.4 \\
F & 14.2 & 1.6 & .4 & 0 & .2 & 1.4 \\
\hline
\end{tabular}

October 27, 1999

\begin{tabular}{|c|c|c|c|c|c|c|}
\hline $\begin{array}{c}\text { Subreach } \\
\text { (see table } 3 \\
\text { for } \\
\text { description) }\end{array}$ & $\begin{array}{c}\text { Mean } \\
\text { streamflow } \\
\text { in subreach }\end{array}$ & $\begin{array}{c}\text { Measured } \\
\text { difference in } \\
\text { streamflow within } \\
\text { subreach }\end{array}$ & $\begin{array}{l}\text { Inflow from creeks } \\
\text { or tributaries } \\
\text { within subreach }\end{array}$ & $\begin{array}{l}\text { Net diversion } \\
\text { in subreach }\end{array}$ & $\begin{array}{l}\text { Estimated } \\
\text { evaporation } \\
\text { loss within } \\
\text { subreach }\end{array}$ & $\begin{array}{c}\text { Estimated } \\
\text { ground-water } \\
\text { inflow within } \\
\text { subreach }\end{array}$ \\
\hline $\bar{A}$ & 5.2 & -1.2 & 0 & 0 & 0.1 & -1.1 \\
\hline B & 14.1 & 4.4 & 4.6 & .1 & .0 & -.3 \\
\hline $\mathrm{C}$ & 17.6 & 3.0 & .9 & 0 & .2 & 2.3 \\
\hline $\mathrm{D}$ & 17.8 & -3.0 & 0 & -3.0 & .3 & .3 \\
\hline E & 15.2 & -2.3 & 0 & -.3 & .8 & -1.2 \\
\hline $\mathrm{F}$ & 15.4 & 2.7 & .3 & 0 & .2 & 2.6 \\
\hline
\end{tabular}

Table 5. Summary of tributary discharges (attributed to shallow ground-water inflow) to subreaches along San Pedro Creek and the San Antonio River during streamflow-measurement surveys, May-October 1999

[In cubic feet per second; positive indicates ground-water inflow to subreach]

\begin{tabular}{lllllll}
\hline \multirow{2}{*}{ Date } & \multicolumn{5}{c}{ Subreach (see table 3 for description) } \\
\cline { 2 - 6 } & A & B & C & D & E & F \\
\hline May 26, 1999 & 0 & 0 & 2.0 & 0 & 0 & 0.4 \\
June 8, 1999 & 0 & 0 & 2.0 & 0 & 0 & .4 \\
July 27, 1999 & 0 & 0 & 1.7 & 0 & 0 & .4 \\
Sept. 27, 1999 & 0 & 0 & 1.0 & 0 & 0 & .4 \\
Oct. 27, 1999 & 0 & 0 & .9 & 0 & 0 & .3 \\
Mean & 0 & 0 & 1.5 & 0 & 0 & .4 \\
\hline
\end{tabular}


Table 6. Summary of estimated shallow ground-water inflow for subreaches along San Pedro Creek and the San Antonio River during streamflow-measurement surveys, May-October 1999

[In cubic feet per second; positive indicates ground-water inflow to subreach; negative indicates streamflow loss to ground water. --, not measured or determined]

\begin{tabular}{lccccccc}
\hline \multirow{2}{*}{ Date } & \multicolumn{7}{c}{ Subreach (see table 3 for description) } \\
\cline { 2 - 7 } & A & B & C-D & C & D & E & F \\
\hline May 26, 1999 & -- & -- & 5.6 & -- & -- & 0.3 & 0.1 \\
June 8, 1999 & -- & -- & 1.8 & 1.2 & 0.6 & -1.5 & .1 \\
July 27, 1999 & 0.4 & 2.1 & 4.1 & .3 & 3.8 & -2.6 & .7 \\
Sept. 27, 1999 & -.3 & .8 & 1.2 & .8 & .4 & -.4 & 1.4 \\
Oct. 27, 1999 & -1.1 & -.3 & 2.6 & 2.3 & .3 & -1.2 & 2.6 \\
Mean & -.3 & .9 & 3.1 & 1.2 & 1.3 & -1.1 & 1.0 \\
\hline
\end{tabular}

\footnotetext{
${ }^{1}$ Subreaches C and D combined for May 26, 1999, measurement survey. Ground-water inflow for combined subreach estimated to be 5.6 cubic feet per second.
}

For San Pedro Creek from Furnish Avenue to the confluence with the San Antonio River and the entire reach of the San Antonio River from Mitchell Street to South Loop 410, the mean estimated ground-water inflow was $3.0 \mathrm{ft}^{3} / \mathrm{s}(1.9 \mathrm{Mgal} / \mathrm{d})$ from direct inflow to the streams and $1.9 \mathrm{ft}^{3} / \mathrm{s}(1.2 \mathrm{Mgal} / \mathrm{d})$ from tributary inflow attributed to ground water. The total estimated ground-water inflow to the study reach thus was 4.9 $\mathrm{ft}^{3} / \mathrm{s}(3.2 \mathrm{Mgal} / \mathrm{d})$.

\section{SUMMARY}

There are two possible sources of ground-water inflow to lower San Pedro Creek and the San Antonio River east of Kelly AFB. One source is direct groundwater inflow to the streams. The other source is ground water that enters tributaries that flow into the San Antonio River.

Four of the six subreaches for which streamflowmeasurement surveys were done during May-October 1999 had gains from shallow ground-water inflows. Only the subreach in lower San Pedro Creek and the subreach in the San Antonio River from the Padre Park dam to Ashley Road had streamflow losses to shallow ground water. For the entire study reach, the estimated mean ground-water inflow was $3.0 \mathrm{ft}^{3} / \mathrm{s}(1.9 \mathrm{Mgal} / \mathrm{d})$.

In addition to direct ground-water inflow, two San Antonio River subreaches (Theo Avenue to Roosevelt Avenue and Ashley Road to South Loop 410) also receive tributary base flow that likely originates from shallow ground water. The average total tributary inflow was $1.9 \mathrm{ft}^{3} / \mathrm{s}(1.2 \mathrm{Mgal} / \mathrm{d})$.

The total ground-water inflow to the study reach (sum of direct ground-water inflow and tributary inflow that originates from ground water) averaged $4.9 \mathrm{ft}^{3} / \mathrm{s}$ (3.2 Mgal/d).

Although the inflow from springs and seeps could not be measured, estimates (by visual observation) of the spring and seep discharges amount to much less than the estimates of ground-water inflow computed from the gain-loss measurements. In fact, during the July 27 , September 27, and October 27 measurements, most of the springs and seeps had diminished or ceased entirely, yet the gain-loss measurements indicated that groundwater inflow was still occurring. Therefore, the presence and location of springs and seeps might not be a reliable indicator of the source of shallow ground-water inflow to the river. Most of the shallow ground water that enters the San Antonio River from tributary inflow enters from the west side, through Concepcion Creek, inflows near Riverside Golf Course, and Six-Mile Creek.

The gain-loss measurements were made during relatively dry conditions, as rainfall before (JanuaryMay) and during the study (May-October) was below normal. During periods of greater rainfall than occurred during the study, shallow ground-water levels could rise causing greater shallow ground-water inflow to the river. 


\section{REFERENCES}

National Oceanic and Atmospheric Administration, 1999, Climatological data annual summary-Texas: Asheville, N.C., U.S. Department of Commerce, National Climatic Data Center, v. 103, no. 13.

Rantz, S.E., and others, 1982, Measurement and computation of streamflow-Volume 1. Measurement of stage and discharge: U.S. Geological Survey Water-Supply Paper 2175, p. 1-284.

Texas Natural Resource Conservation Commission, 1999, Water rights download file: Accessed October 15, 1999, at URL

http://www.tnrcc.state.tx.us/permitting/waterperm/ wrpa/permits.html\#databases 
District Chief

U.S. Geological Survey

8027 Exchange Dr.

Austin, TX 78754-4733 